\title{
Popular Sovereignty and Constitutional Referendum: Can "The People" be Limited by Human Rights?
}

\author{
Ignatius Yordan Nugraha ${ }^{1}$ (D) \\ ${ }^{1} \mathrm{PhD}$ Research Fellow, Hasselt University, Hasselt, Belgium \\ Corresponding author: yordan.nugraha@uhasselt.be
}

(Received 23 November 2020; accepted 26 July 2021)

\begin{abstract}
The rise of referendums has led to the concern that they could lead to liberticide and discriminatory results. This article intends to determine whether the concept of popular sovereignty would immunize constitutional provisions that are passed through a constitutional referendum from any human rights limitation. In answering the question, I formulate a theoretical framework called "constituent-constituted duality," while also distinguishing "the constituent people," which is mythical, and "the constituted people," which is empiric. In the end, this article argues that the only possible form of limitation from the perspective of popular sovereignty is an ex ante limitation. Meanwhile, an ex post facto limitation remains unacceptable from the angle of popular sovereignty, which implies that a judicial review of popularly-enacted constitutional amendments is conceptually illegitimate.
\end{abstract}

Keywords: Referendum; popular initiative; human rights; constitution; popular sovereignty

\section{A. Introduction}

"The people" are sovereign. That is the formula most modern constitutions around the world have adopted. ${ }^{1}$ Many states have also translated this concept into the possibility for citizens to have a direct say on constitutional making and changing through the use of a referendum. ${ }^{2}$ When "the people" cast their judgment upon the subject matter presented to them, their word is often considered to be "sacrosanct," "final," and "binding." As the title of a 1709 Whig Party tract put it, "Vox Populi, Vox Dei."”

\footnotetext{
Ignatius Yordan Nugraha is a PhD research fellow at Hasselt University in Belgium. The research for this article was conducted during the author's PhD project "Clashes between International Human Rights Law and Constitutional Law? LGB Rights as a Case Study," which is sponsored by the Special Research Fund (BOF) of Hasselt University (grant ID: BOF20OWB11).

${ }^{1}$ For instance, the first recital of the Preamble of the Bangladeshi Constitution reads, "We, the people of Bangladesh ... established the independent, sovereign People's Republic of Bangladesh." গণপূরজাতন্তররী বাংলাদশেরে সংবধিाন [Constitution of the People's Republic of Bangladesh] Nov. 4, 1972, pmbl. Similarly, the 1937 Irish Constitution also contains the formula "We, the people of Éire." CONSTITUTION OF IRELAND 1937 pmbl., https://www.irishstatutebook.ie/eli/ cons/en/html.

${ }^{2}$ See, e.g., Ustava Republike Slovenije [Constitution of the Republic Slovenia] Dec. 23, 1991, art. 170 (amended 2016); see also Dustūr Jumhūrìyat Miıșr AL-'Arabìyah [Constitution of the Arab Republic of Egypt], Jan. 18, 2014, art. 226 (amended 2019).

${ }^{3}$ Daniel Defoe, John Dunton \& John Somers, Vox Populi, Vox Dei: Being True Maxims of Government (Gale Ecco 2018) (1709).
}

(C) The Author(s) 2022. Published by Cambridge University Press on behalf of the German Law Journal. This is an Open Access article, distributed under the terms of the Creative Commons Attribution licence (https://creativecommons.org/licenses/by/4.0/), which permits unrestricted re-use, distribution, and reproduction in any medium, provided the original work is properly cited. 
The concept of popular sovereignty, however, has raised a commonly-expounded criticism that it could lead to the "tyranny of the majority" whereby, as James Madison put it, "measures are too often decided, not according to the rules of justice and the rights of the minor party, but by the superior force of an interested and overbearing majority." 4 There is also the concern that referendums are prone to elite manipulation leading to discriminatory and liberticide results, ${ }^{5}$ particularly during the era of populists and demagogues. ${ }^{6}$ An example is the 2009 Swiss minaret referendum which led to the constitutional prohibition of the construction of new minarets. ${ }^{7}$ While referendum results are not always detrimental to minority interests, there seems to be a heightened risk for "unpopular" minorities such as homosexuals and immigrants. ${ }^{8}$

This particular problem with referendums has highlighted an uneasy tension between popular sovereignty and human rights. On the one hand, the position that favors human rights is aptly illustrated by the statement of Justice Robert H. Jackson of the American Supreme Court in the case of West Virginia State Board of Education v. Barnette concerning students who were expelled from a public school after conscientiously refusing to salute the Star-Spangled Banner. In response to the admonishment that the removal of "unwise laws" needs to be effectuated through a referendum instead of the courts, Jackson asserted that:

The very purpose of a Bill of Rights was to withdraw certain subjects from the vicissitudes of political controversy, to place them beyond the reach of majorities and officials and to establish them as legal principles to be applied by the courts. One's right to life, liberty, and property, to free speech, a free press, freedom of worship and assembly, and other fundamental rights may not be submitted to vote; they depend on the outcome of no elections. ${ }^{9}$

On the other hand, according to Richard Parker, constitutions are embedded within the idea of populism in the sense that the people are free to shape and reshape society as they wish. ${ }^{10}$ Moreover, as observed by Marthe Fatin-Rouge Stéfanini, popular sovereignty implies that "the sovereign people, original holder of power, are by nature unlimited." ${ }^{\prime 1}$ As a result, if these ideas were to be taken at face value, it would seem to imply that the people's sovereignty cannot be constrained by any form of limitation, including human rights.

With this debate in mind, the purpose of this article is to analyze whether popular sovereignty would immunize a constitutional amendment that is passed through the mechanism of constitutional referendum from any form of human rights limitation. I will call this sort of amendment "popularly-enacted constitutional amendment." In answering the research question, my approach will be two-pronged. First, I will undertake a comparative study of how different jurisdictions have dealt with the issue of potential human rights limitations to popularly-enacted constitutional

\footnotetext{
${ }^{4}$ The Federalist No. 10, at 42 (James Madison) (George W. Carey \& James McClellan eds., 2001). See also Simone Chambers, Making Referendums Safe for Democracy: A Call for More and Better Deliberation, 24 SwISS POL. SCI. REV. 305 (2018).

${ }^{5}$ See Justin Blount \& Tom Ginsburg, Participation in Constitutional Design: Asian Exceptionalism, in Comparative Constitutional Law in Asia 23, 39 (Rosalind Dixon \& Tom Ginsburg eds., 2011).

${ }^{6}$ See Marthe Fatin-Rouge Stefanini, Referendums, Minorities and Individual Freedoms, in THE RouTLEDGE HANDBOOK TO Referendums and Direct Democracy 371, 377-78 (Laurence Morel \& Matt Qvortrup eds., 2018). See also Marthe FatinRouge Stéfanini, Le Référendum et la Protection des Droits Fondamentaux [The Referendum and the Protection of Fundamental Rights], 53 Revue Française De Droit Constitutionnel 73, 75-86 (2003); Liubomir Topaloff, The Rise of Referendums: Elite Strategy or Populist Weapon?, 28 J. DEMOCR. 127 (2017).

${ }^{7}$ See Maya Hertig Randall, Direct Democracy in Switzerland: Trends, Challenges and the Quest for Solutions, in Contemporary Voting in Europe: Patterns and Trends 129, 130 (Alexis Chommeloux \& Elizabeth Gibson-Morgan eds., 2017).

${ }^{8}$ See Stefanini (2018), supra note 6, at 376-78.

${ }^{9}$ W. Va. State Bd. of Educ. v. Barnette, 319 U.S. 624, 639 (1943).

${ }^{10}$ See Richard D. Parker, "Here, the People Rule": A Constitutional Populist Manifesto, 27 VAL. U. L. ReV. 531, 583 (1993).

${ }^{11}$ See Stefanini (2018), supra note 6, at 372.
} 
amendments. Second, I will conduct a normative analysis focusing on the concept of sovereignty as applied to constitutional referendums and the people. Therefore, the starting point here will be sovereignty itself instead of its corollary, the concept of constituent power, that has often been used in constitutional law scholarship. ${ }^{12}$ As a note, the term "human rights" in this article covers both positive rights—as enshrined in the constitution or international human rights law — and natural rights.

The research will be structured as follows. Section B will commence with the comparative study of how various states have grappled with the issue of popularly-enacted constitutional amendment and human rights. Section $C$ will move toward the theoretical aspect by dissecting the concept of "sovereignty." This section will scrutinize "constituent" and "constituted" sovereignty as applied to "the people," and will demonstrate how both are applicable at the same time in the context of constitutional referendums. I will refer to this simultaneous applicability as the "constituentconstituted duality." Afterwards, Section D will analyze whether this concept leaves room for either an ex ante or ex post facto limitation to a popularly-enacted constitutional amendment. The analysis will also consider whether limitation based on human rights would carry more weight in comparison with other forms of limitation. Finally, this article will conclude whether human rights can legitimately limit a popularly-enacted constitutional amendment in a constitutional order based on popular sovereignty.

\section{B. Comparative Study of Human Rights Limitation to Popularly-Enacted Constitutional Amendment}

If the people are sovereign, does it mean that their judgment to pass a constitutional amendment can never be subject to any limitation? This section explores how different jurisdictions have tackled the issue of a potential human rights limitation to a popularly-enacted constitutional amendment. The approach of this section will be two-pronged. First, there will be a general overview of whether constitutions around the world enshrine a human rights limitation to a popularlyenacted constitutional amendment. Second, it will analyze how courts have dealt with the question of potential human rights limitations to popularly-enacted constitutional amendment. For the second part, this section will focus on two states that best illustrate the matter, namely Switzerland and Ireland. The reason for this selection is that Switzerland and Ireland are among states who have organized the most constitutional referendums in the world. ${ }^{13}$ In these countries, there is extensive constitutional jurisprudence with regard to whether popularly-enacted constitutional amendments can be subject to any form of human rights limitations. In the end, these two states have a common thread in that the people's judgment is still final and binding.

\section{Human Rights Limitation in Various Constitutions}

The use of referendums to ratify constitutional amendments has proliferated in recent decades. According to Zachary Elkins and Alexander Hudson, fifty-nine percent of constitutions of independent states in the year 2013 provided for referendums to approve constitutional amendments, while twenty-one percent allowed citizens to initiate a constitutional amendment proposal. ${ }^{14}$ As an example, Article 78 of the Latvian Constitution provides that "[e]lectors, in number comprising not less than one-tenth of the electorate, have the right to submit a fully elaborated draft of an

\footnotetext{
${ }^{12}$ See, e.g., Yaniv Roznai, Unconstitutional Constitutional Amendments (2017). See also Joel Colón-Ríos, CONSTituent POWER AND THE LAW (2020).

${ }^{13}$ See Zachary Elkins \& Alexander Hudson, The Constitutional Referendum in Historical Perspective, in COMPARATIVE Constitution Making 142, 152 (David Landau \& Hanna Lerner eds., 2019).

${ }^{14}$ See id. at 148-50. See also Tom Ginsburg, Zachary Elkins \& Justin Blount, Does the Process of Constitution-Making Matter?, 5 Ann. Rev. L. \& Soc. Sci. 201, 206-07 (2009) (finding that the proportion of constitutions specifically requiring public ratification through referendums has risen from around five percent in 1950 to around forty percent in the $2000 \mathrm{~s}$ ).
} 
amendment to the Constitution," and that "[i]f the Saeima [Parliament] does not adopt it without change as to its content, it shall then be submitted to national referendum."15

Many constitutions have prescribed an explicit limitation to a constitutional amendment in general. ${ }^{16}$ In terms of content, Yaniv Roznai has identified "several common protected components," such as form and system of government, political or governmental structure, fundamental ideology or identity, and state and national integrity. ${ }^{17}$ Most notably, for the purpose of this research, one of the most common protected components is fundamental rights and freedoms. ${ }^{18}$ As an illustration, Article 288 of the Portuguese Constitution stipulates that "[c]onstitutional revision laws shall respect: ... [c]itizens' rights, freedoms and guarantees."19

With respect to whether this human rights limitation also applies to popularly-enacted constitutional amendments, only a few constitutions expressly enshrine a provision stipulating that constitutional referendums cannot be organized if the subject matter would lead to the abolition or constraint of existing rights. For instance, Article 155 of the Azerbaijani Constitution enshrines that:

Proposals for a referendum cannot be introduced concerning ... the abolition of the rights and freedoms of man and citizen, provided for in Chapter III of the present Constitution, to a higher degree than is provided for by international agreements to which the Republic of Azerbaijan is a party. ${ }^{20}$

Article 441 and 442 of the Ecuadorian Constitution also stipulate that amendments by means of a referendum are only possible if they do not set any constraint on constitutional rights and guarantees. ${ }^{21}$ Moreover, Article 32 of the Peruvian Constitution, while allowing referendums on "partial or complete amendment of the Constitution," specifically prohibits referendums concerning "abolition or abridgement of the fundamental rights of the person." 22 Meanwhile, as will be explored further in the following subsection, Article 139(3) of the Swiss Constitution requires that a popular initiative to amend the constitution may not infringe "mandatory provisions of international law."23

Among constitutions that provide for the mechanism of a constitutional referendum, there are also those that do not expressly prohibit the holding of a constitutional referendum with subject matter that is contrary to human rights, but the existence of such a prohibition can still be inferred from the unamendability of human rights provisions in these constitutions. This sort of prohibition can be found in the constitutions of Algeria, ${ }^{24}$ the Central African Republic, ${ }^{25}$

\footnotetext{
${ }^{15}$ Latvijas Republikas Satversme [Constitution of the Republic of Latvia] Feb. 15, 1922, art. 78 (revised 2016).

${ }^{16}$ See RoZNAI, supra note 12 , at $21-37$.

${ }^{17}$ See id. at 23-25. See also Gábor Halmai, Judicial Review of Constitutional Amendments and New Constitutions in Comparative Perspective, 13 WAKE FOREST L. REV. 101 (2016).

${ }^{18}$ See RozNAI, supra note 12 , at 25.

${ }^{19}$ Constituição da República Portuguesa [C.R.P.] [Constitution of the Republic of Portugal] Apr. 2, 1976, art. 288 (amended 2005).

${ }^{20}$ See Azərbaycan Respublikasinin Konstitusiyasi [Constitution of the Republic of Azerbaijan] Nov. 12, 1995, art. 155 (amended 2016).

${ }^{21}$ See Constitución de la República del Ecuador [Constitution of the Republic of Ecuador] Oct. 20, 2008, arts. 441, 442 (amended 2012).

${ }^{22}$ Constitución Política del Perú [Political Constitution of Peru] Dec. 29, 1993, art. 32 (revised 2009). See also Tribunal Constitucional [Constitutional Court] Nov. 2, 2005, Opinion No. 0024-2005-PI/TC (Peru).

${ }^{23}$ Bundesverfassung [BV] [Constitution] Apr. 18, 1999, SR 101, art. 139(3) (Switz.) (amended 2014).

${ }^{24}$ Constitution de la République Algérienne Démocratique et Populaire [Constitution of the Democratic and People's Republic of Algeria] Nov. 1, 2020, arts. 230, 234.

${ }^{25}$ Constitution de la République Centrafricaine [Constitution of the Central African Republic] Mar. 27, 2016, arts. 152,153 .
} 
Chad ${ }^{26}$ the Democratic Republic of Congo, ${ }^{27}$ Egypt $^{28}{ }^{28}$ Moldova, ${ }^{29}$ Morocco, ${ }^{30}$ Namibia,${ }^{31}$ Romania, ${ }^{32}$ Timor Leste, ${ }^{33}$ and Ukraine. ${ }^{34}$

As an illustration, Article 234 of the Algerian Constitution stipulates that constitutional amendment shall not undermine "the fundamental freedoms and the human and citizens' rights." ${ }^{35}$ If Article 230 of the Algerian Constitution, which requires a constitutional amendment to be approved by referendum, ${ }^{36}$ is read in conjunction with Article 234, it implies the existence of a prohibition of a constitutional referendum whose approval would lead to the undermining of human rights. In a similar vein, Article 152(2) of the Romanian Constitution states that no constitutional amendment shall be adopted "if it would result in the elimination of the fundamental rights and freedoms of citizens or of the guarantees of these rights and freedoms." ${ }^{37}$ Given that a constitutional amendment can only enter into force after a constitutional referendum, ${ }^{38}$ it suggests that there shall be no constitutional referendum whose subject matter is concerned with the elimination of existing rights. ${ }^{39}$

At the same time, there are also constitutions that have used constitutional referendum to further entrench constitutional provisions concerning human rights instead of establishing human rights as a limitation to constitutional referendum. This sort of approach can be found in Armenia, ${ }^{40}$ Belarus, ${ }^{41}$ Bolivia, ${ }^{42}$ Colombia,${ }^{43}$ the Dominican Republic, ${ }^{44}$ Eswatini, ${ }^{45}$ the

\footnotetext{
${ }^{26}$ La Constitution de la République du Tchad [The Constitution of the Republic of Chad] May 4, 2018, arts. 226, 227.

${ }^{27}$ Constitution de la République Démocratique du Congo [Constitution of the Democratic Republic of Congo] Feb. 18, 2006, arts. 218, 220 (amended 2011).

${ }^{28}$ Dustúr Jumhürīyat Mișr AL-'Arabī̄yah [Constitution of the Arab Republic of Egypt], Jan. 18, 2014, art. 226 (amended 2019).

${ }^{29}$ Constituția Republici Moldova [Constitution of the Republic of Moldova] Aug. 27, 1994, art. 142(1)-(2) (amended 2016).

${ }^{30}$ Constitution du Royaume du Maroc [Constitution of the Kingdom of Morocco] July 1, 2011, arts. $174,175$.

${ }^{31}$ Constitution of the Republic of Namibia Feb. 9, 1990, art. 132(3), (5) (amended 2014).

${ }^{32}$ Constituția României [Romanian Constitution] Dec. 8, 1991, arts. 151(3), 152(2) (amended 2003).

${ }^{33}$ Constituição da República Democrática de Timor-Leste [Constitution of the Democratic Republic of Timor-Leste] May 22, 2002, arts. 156(1)-(2).

${ }^{34}$ КОНСТИТУЦІя УКРАїнИ [CONSTITUTION OF UKRAine] June 28, 1996, arts. 156, 157 (amended 2016).

${ }^{35}$ Constitution de la République Algérienne Démocratique et Populaire [Constitution of the Democratic AND People's Republic of Algeria] Nov. 1, 2020, art. 234.

${ }^{36} \mathrm{See} i d$. at art. 230.

${ }^{37}$ Constituția României [Romanian Constitution] Dec. 8, 1991, art. 152(2) (amended 2003).

${ }^{38}$ See id. at art. 151(3).

${ }^{39} \mathrm{Cf}$. Romanian Constitutional Court, July 20, 2016, OfFicial GaZETTE OF Romania, Part I, no. 857 of 27 October 2016 , Decision No. 580; Marieta Safta, Constitutional Court of Romania: The Constitutionality of the Citizens' Initiative for the Revision of Article 48 (1) of the Constitution ('Family'), 11 ICL J. 315 (2017). In this case, the Court had to decide whether a constitutional referendum to amend Article 48(1) on the right to marry is permissible in light of the human rights limitation under Article 152(2). The proposed amendment was intended to change the words "of the spouses" into "between a man and a woman." The Court decided to allow the constitutional referendum under the ground that this change of word is a mere clarification of the scope of Article 48, as the Court believes that at the time when the Article was adopted, marriage was only understood in the traditional sense. Thus, for the Court, the subject matter of the referendum would not lead to the elimination of the right to marry nor the undermining of its guarantees. Nevertheless, the constitutional referendum eventually failed due to low turnout.

${ }^{40}$ Hayastani Hanrapetut'yan Sahmanadrut'yun [Constitution of the Republic of Armenia] July 13, 1995, art. 202(1) (revised 2015).

${ }^{41}$ КонСтитУция РеСпуьлики БЕлАрусь [Constitution of the Republic of Belarus] Mar. 30, 1994, art. 140 (revised 2004).

${ }^{42}$ Constitución de 2009 del Estado Plurinacional de Bolivia [2009 Constitution of the Plurinational State of Bolivia] Feb. 7, 2009, art. 411.

${ }^{43}$ Constitución Política de Colombia [C.P.] [Constitution of Colombia] art. 377 (amended 2015).

${ }^{44}$ Constitución Política de la República Dominicana [Political Constitution of the Dominican Republic] July 10, 2015, art. 272 .

${ }^{45}$ The Constitution of The Kingdom of Swaziland Act 2005, art. 246 (Eswatini).
} 
Gambia ${ }^{46}$ Ghana, ${ }^{47}$ Iraq, ${ }^{48}$ Kenya,${ }^{49}$ Malawi, ${ }^{50}$ the Maldives, ${ }^{51}$ Mozambique, ${ }^{52}$ Russia, ${ }^{53}$ and Serbia. ${ }^{54}$ As an example, Article 272 of the Dominican Republic's Constitution stipulates that constitutional reform concerning "rights, fundamental guarantees and duties ... shall require the ratification of the majority of the male and female citizens with electoral rights, in an approval referendum ...." 55

Among the constitutions that have explicitly or implicitly prohibited constitutional referendums whose subject matter is contrary to human rights, some have expressly resorted to an ex ante limitation, which refers to preventive control of constitutional amendment proposals before a constitutional referendum can be organized. This mechanism can be found in Algeria, ${ }^{56}$ Azerbaijan, ${ }^{57}$ the Central African Republic, ${ }^{58}$ Ecuador, ${ }^{59}$ Moldova, ${ }^{60}$ Romania, ${ }^{61}$ and Switzerland. ${ }^{62}$ For instance, Article 140(1) of the Ecuadorian Constitution establishes the competence for the Constitutional Court to issue "a prior and binding ruling of constitutionality" with respect to "calls to referendums nationwide." 63

Ex ante limitation is to be contrasted with ex post facto limitation, which is concerned with reviewing of constitutional provisions that are already adopted through a constitutional referendum. In this regard, there seems to be no constitutional provision that expressly establishes an ex post facto limitation for a popularly-enacted constitutional amendment. ${ }^{64}$ Instead, there is a constitutional provision that prohibits such a limitation. Article 154 of the Azerbaijani Constitution stipulates that a popularly-enacted constitutional amendment may not be subject to any review by the Constitutional Court. ${ }^{65}$ Nevertheless, in order to understand whether courts in different jurisdictions have assumed the competence to undertake an ex post facto review of a popularly-enacted constitutional amendment based on human rights, one would need to dig deeper into specific jurisdictions, and this will be the focus of the following subsections.

\footnotetext{
${ }^{46}$ Constitution of the Republic of the Gambia Aug. 8, 1996, art. 226(4), (7e) (amended 2018).

${ }^{47}$ Constitution of the Republic of Ghana May 8, 1992, art. 290 (revised 1996).

${ }^{48}$ Dustúr Jumhüríyat aL-'IrĀQ [The Constitution of the Republic of Iraq] 2005, art. 126(2).

${ }^{49}$ The Constitution of Kenya, 2010, art. 255(1).

${ }^{50}$ Constitution of the Republic of Malawi May 16, 1994, art. 196 (amended 2017).

${ }^{51}$ Constitution of the Republic of Maldives Aug. 7, 2008, art. 262(b).

${ }^{52}$ Constituição da República de Mozambique [Constitution of the Republic of Mozambique] Nov. 16, 2004, art. 292 (amended 2007).

${ }^{53}$ КОНСТИТУЦИя РОССИЙСКОЙ ФЕДЕРАЦИИ [CONSTITUtion of the Russian Federation] art. 135 (amended 2014).

${ }^{54}$ УСтав СРьИје [Constitution of Serbia] Nov. 8, 2006, art. 203.

${ }^{55}$ Constitución Política de la República dominicana [Political Constitution of the Dominican Republic] July 10, 2015, art. 272.

${ }^{56}$ Constitution de la République Algérienne Démocratique et Populaire [Constitution of the Democratic ANd People's Republic of Algeria] Nov. 1, 2020, art. 210.

${ }^{57}$ Azorbaycan RespubliKasinin Konstitusiyasi [Constitution of the Republic of Azerbaijan] Nov. 12, 1995, art. 153 (amended 2016).

${ }^{58}$ Constitution de la République Centrafricaine [Constitution of the Central African Republic] Mar. 27, 2016, art. 95.

${ }^{59}$ Constitución de la República del Ecuador [Constitution of the Republic of Ecuador] Oct. 20, 2008 , art. 438.

${ }^{60}$ Constituția Republicil Moldova [Constitution of the Republic of Moldova] Aug. 27, 1994, art. 135(1c) (amended 2016).

${ }^{61}$ Constituția României [Romanian Constitution] Dec. 8, 1991, art. 146(a) (amended 2003).

${ }^{62}$ Bundesverfassung [BV] [CONSTitution] Apr. 18, 1999, SR 101, art. 173(1f) (Switz.) (amended 2014).

${ }^{63}$ Constitución de la República del Ecuador [Constitution of the Republic of Ecuador] Oct. 20, 2008 , art. 438.

${ }^{64}$ See Lech Garlicki \& Zofia Garlicka, Review of Constitutionality of Constitutional Amendments (an Imperfect Response to Imperfections?), 1 ANAYASA HUKUKU DERGISI 185, 208 (2012) (finding that constitutional provisions that explicitly establish a judicial review mechanism for ordinary constitutional amendment itself remains rare, and usually the jurisdiction is only restricted to the draft amendment). See also RoZNAI, supra note 12, at 197-98.

${ }^{65}$ See Azərbaycan Respublikasinin Konstitusiyasi [Constitution of the Republic of Azerbaijan] Nov. 12, 1995, art. 154 (amended 2016).
} 


\section{Human Rights Limitation in Switzerland?}

Switzerland is renowned for its referendum practice. Article 140(1) of the 1999 Constitution stipulates that amendments to the Federal Constitution must be put to a public vote. ${ }^{66}$ Thus, Switzerland has a mechanism of "mandatory referendum." Moreover, Swiss citizens can not only react to top-down amendment proposals, but also initiate their own amendment process and shape the content. ${ }^{67}$ Under Article 138 and 139 of the Constitution, 100,000 citizens who are eligible to vote may propose a total or partial revision of the Constitution. ${ }^{68}$ Such a measure is called "popular initiative." 69 The proposal will also be submitted to a vote, and if it is approved by the majority of voters and the cantons, the constitutional amendment will be adopted. ${ }^{70}$

Recently, there has been a rise of popular initiatives whose subject matter is detrimental to the rights of unpopular minorities. ${ }^{71}$ A notable example is the 2009 popular initiative "against the construction of minarets." ${ }^{\prime 2}$ The electorate approved the proposal, and consequently, Article $72(3)$ of the Constitution now reads, "[t]he construction of minarets is prohibited." scholars such as Giovanni Biaggini believe that this new constitutional norm is not in line with international human rights law, ${ }^{74}$ there is a direct conflict between Swiss popular sovereignty and human rights law. ${ }^{75}$ This would raise the question of whether the latter could prevail over the former. Within the context of popular initiatives, this question could be approached from two angles: ex ante and ex post facto.

With regard to ex ante control, Article 139(3) of the Constitution lists three requirements a popular initiative must fulfill before it can be submitted to a public vote. Most notably, this provision stipulates that a popular initiative must not infringe "mandatory provisions of international law."76 If a popular initiative failed to fulfill this requirement, the Federal Assembly could declare it to be invalid in whole or in part after considering the advice of the Federal Council. ${ }^{77}$ In practice, the Federal Assembly would apply the in dubio pro populo principle. This principle stipulates that the authorities shall interpret popular initiatives in such a way as to avoid conflict with mandatory principles of international law so that the initiative concerned would not have to be invalidated. ${ }^{78}$ The Federal Council has even considered this particular practice as an obligation emanating from

\footnotetext{
${ }^{66}$ See Bundesverfassung [BV] [COnstitution] Apr. 18, 1999, SR 101, art. 140(1) (Switz.) (amended 2014).

${ }^{67}$ See Lorenz Langer, Panacea or Pathetic Fallacy? The Swiss Ban on Minarets, 43 VAND. J. INT'L. L. 1, 7 (2010).

${ }^{68}$ See Bundesverfassung [BV] [Constitution] Apr. 18, 1999, SR 101, art. 138, 139 (Switz.) (amended 2014).

${ }^{69}$ Daniel Moeckli, Of Minarets and Foreign Criminals: Swiss Direct Democracy and Human Rights, 11 HUM. RTs. L. REV. 774, 776 (2011).

${ }^{70}$ See Bundesverfassung [BV] [Constitution] Apr. 18, 1999, SR 101, art. 142 (Switz.) (amended 2014).

${ }^{71}$ See Moeckli, supra note 69, at 780. See also AlEXANDER Misic \& Nicole Töpperwien, Constitutional LAW IN Switzerland 78 (2018); Maya Hertig Randall \& Eleanor McGregor, Reconciling Direct Democracy and Fundamental Rights: The Case of the Swiss Minaret Initiative, Tijdschrift VOOR Constitutioneel Recht 428, 428-29 (2010); Randall, supra note 7, at 134.

${ }^{72}$ See Langer, supra note 67. See also Moeckli, supra note 69.

${ }^{73}$ Bundesverfassung [BV] [CONSTitution] Apr. 18, 1999, SR 101, art. 72(3) (Switz.) (amended 2014).

${ }^{74}$ See Giovanni Biaggini, Die schweizerische direkte Demokratie und das Völkerrecht: Gedanken aus Anlass der Volksabstimmung über die Volksinitiative "Gegen den Bau von Minaretten" [Swiss Direct Democracy and International Law: Thoughts on the Occasion of the Referendum on the Popular Initiative "Against the Building of Minarets"] 62 ZEITSCHRIFT FÜR ÖFFENTLICHES RECHT 325 (2010); see also Langer, supra note 67.

${ }^{75}$ See Marcel Stüssi, Banning of Minarets: Addressing the Validity of a Controversial Swiss Popular Initiative, 3 RELIGION \& HuM. RTs. 135, 152 (2008).

${ }^{76}$ The other two requirements are consistency of form and consistency of subject matter. As explained by Moeckli, "First, the initiative must take the form of either a general proposal or a specific draft, but not a hybrid between the two. Second, it must observe the single-subject rule." See Moeckli, supra note 69, at 781. See also Daniel Moeckli, The Legal Limits of Popular Initiatives in Switzerland, 5 PÁZMÁNY L. REV. 217, 220 (2017); Biaggini, supra note 74, at 329-30.

${ }^{77}$ See Bundesverfassung [BV] [Constitution] Apr. 18, 1999, SR 101, art. 139(3) (Switz.) (amended 2014).

${ }^{78}$ See FF 2010 2067, 2117 (2010), https://www.fedlex.admin.ch/eli/fga/2010/383/fr. See also Randall, supra note 71, at 136; Biaggini, supra note 74, at 330; Giovanni Biaggini, Switzerland, in How Constitutions Change: A Comparative Study 303, 317 (Dawn Oliver \& Carlo Fusaro eds., 2011).
} 
Article 5(3) and 5(4) of the Constitution, which enshrine respectively that state institutions shall act in good faith and that they shall respect international law. ${ }^{79}$ As for the scope of "mandatory provisions," the Federal Assembly and the Federal Council have interpreted the term to include jus cogens norms or fundamental norms of international law that can never be derogated in any circumstances. ${ }^{80}$ The Federal Council has also stated that this term includes non-derogable rights under Article 15 of the European Convention on Human Rights (ECHR). ${ }^{81}$

Hitherto, only two popular initiatives have been declared to be fully or partially invalid due to their repugnancy to mandatory provisions of international law. ${ }^{82}$ In July 1992, a popular initiative titled "for a sensible asylum policy" was launched by the Swiss Democrats. It proposed a constitutional provision that would allow the immediate deportation of asylum seekers who have entered Switzerland illegally and those whose asylum request has been definitively rejected. ${ }^{83}$ The Federal Council observed that the provision required an immediate expulsion without any possibility of appeal. Consequently, its implementation would have violated the principle of non-refoulement under international law. ${ }^{84}$ In its opinion, the Council also made a distinction between "conventional" international law and jus cogens obligations. If a popular initiative is contrary to the former, the Council found that Switzerland could simply terminate its participation in the respective treaty. ${ }^{85}$ If a popular initiative is contrary to the latter, however, Switzerland cannot in any way derogate its jus cogens obligations. ${ }^{86}$ Because the Council held that the principle of nonrefoulement has attained jus cogens status, Switzerland is also unable to simply desist from its non-refoulement obligation. ${ }^{87}$

The Council further hypothesized that the entry into force of such a constitutional provision would lead to two different scenarios. First, Switzerland would be required not to apply the constitutional provision. For the Council, this solution is unacceptable from a democratic perspective. Second, Switzerland would be forced to violate a jus cogens norm. This particular solution is also unacceptable from the perspective of the Rechsstaat. The Council opined that violating the jus cogens norm of non-refoulement would cause "an irreparable damage both to our country and to those who are affected by the initiative and are in need of protection." 88 Thus, the Council concluded:

The sovereign would find itself in the same legal impasse if the initiative were to be put to vote. That is why in reality there is no possibility for the citizen to freely demonstrate their will in this case. A popular vote on the provisions in question constitute a perversion of the democratic order of our country and would transform the exercise of popular rights into a farce. $^{89}$

\footnotetext{
${ }^{79}$ See FF 2010 2067, supra note 78, at 2108.

${ }^{80}$ See Randall \& McGregor, supra note 71, at 431. See also Moeckli, supra note 69, at 781; Erika de Wet, The Prohibition of Torture as an International Norm of Jus Cogens and Its Implication for National and Customary Law, 15 EUR. J. INT'L L. 97, 101 (2004); Goran Seferovic, Direkte Demokratie und Völkerrecht in der Schweiz: Nationaler Identifikationsfaktor im Widerstreit mit internationalem Recht [Direct Democracy and International Law in Switzerland: National Identification Factor in Conflict

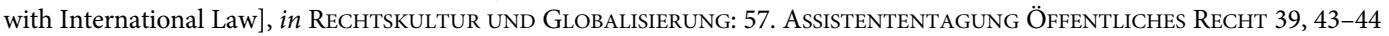
(Sebastian Piecha, Anke Hollijesiefken, Jens Fischer, Stefanie K. Haas, Johanna F. Herberg, Stefan Kracht, \& Yury Safoklov eds., 2017).

${ }^{81}$ See FF 2013 8493, 8503 (2013), https://www.fedlex.admin.ch/eli/fga/2013/1879/fr.

${ }^{82}$ See Moeckli (2017), supra note 76, at 221.

${ }^{83}$ See FF 1994 III 1471 (1994), https://www.fedlex.admin.ch/eli/fga/1994/3_1486_1471_1338/fr.

${ }^{84} \mathrm{See}$ id. at 1484.

${ }^{85} \mathrm{See}$ id. at 1481.

${ }^{86} \mathrm{See}$ id. at 1483.

${ }^{87}$ See id. at 1486 .

${ }^{88}$ See id. at $1486-87$.

${ }^{89} \mathrm{Id}$. at 1487.
} 
Therefore, the Federal Council recommended that the popular initiative should be declared void even though at that time there was no constitutional provision that established an ex ante limitation based on "mandatory provisions of international law." Eventually, the Federal Assembly followed the advice of the Council in March 1996, ${ }^{90}$ and the ex ante limitation was subsequently inserted in the 1999 Constitution.

Meanwhile, the second initiative was launched in 2012 by the Swiss People's Party with the title "for the effective expulsion of foreign criminals (initiative of implementation)." One of the constitutional provisions proposed by this initiative was intended to define the term "mandatory provisions of international law" by narrowing it down to the prohibition of torture, genocide, aggression, slavery, and also the prohibition of refoulement to a state where the person concerned is at risk of being tortured or killed. ${ }^{91}$ In 2015, the Federal Assembly invalidated this particular provision based on the advice of the Federal Council, although the other proposed provisions passed the ex ante control and were put to a public vote. ${ }^{92}$ According to the Council, jus cogens norms are defined by the international community. Consequently, Switzerland cannot unilaterally expand or restrict this definition. The Council also found that restricting the definition of jus cogens could give rise to violations, particularly if the definition is not in conformity with what is accepted by the international community as a whole. ${ }^{93}$

As for ex post facto control, the jurisprudence of the Federal Supreme Court of Switzerland seems to demonstrate the possibility of not applying a popularly-enacted constitutional provision that is deemed to be contrary to international human rights law. ${ }^{94}$ In 2010 , a popular initiative by the Swiss People's Party on the expulsion of "foreign criminals" was approved by the Swiss Electorate. The initiative inserted, among others, Article 121(3) into the Constitution. This provision stipulates that the residence permit of foreigners who have been convicted of various crimes, including drug trafficking, shall be rescinded, and they shall subsequently be expelled from the country. In judgment number 2C_828/2011, the Second Division of the Federal Supreme Court had to decide whether the existence of this provision implies that the deportation order of a young Macedonian drug dealer must proceed even though he has long settled in that country. ${ }^{95}$

According to the Court, if Article 121(3) were to be interpreted in isolation, the automatic expulsion of foreign criminals would cause a conflict with the ECHR because this provision does not distinguish between serious crimes and misdemeanors, and also because it excludes assessment and balancing of interests as required by the Convention. ${ }^{96}$ Nevertheless, the Court found that Article 121(3) of the Constitution is dealing with an "open norm" (offene Norm) that requires "fine-tuning" (Feinabstimmung) by the legislature, which would include the effort to strike a balance between Article 121(3), other constitutional norms, and international law. In other words, the provision is deemed to not be directly applicable without the adoption of implementing legislation in accordance with the ECHR jurisprudence. ${ }^{97}$ As a result, the Court decided not to apply the provision. ${ }^{98}$

\footnotetext{
${ }^{90}$ See FF 1996 I 1305 (1996), https://www.fedlex.admin.ch/eli/fga/1996/1_1355_1305_1157/fr.

${ }^{91}$ See FF 2013 8493, supra note 81, at 8500.

${ }^{92}$ See FF 20152487 (2015), https://www.fedlex.admin.ch/eli/fga/2015/542/fr.

${ }^{93}$ See FF 2013 8493, supra note 81, at 8506.

${ }^{94}$ See Rosalind Dixon \& Felix Uhlmann, The Swiss Constitution and a Weak-Form Unconstitutional Amendment Doctrine?, 16 InT'L J. CONST. L. 54, 62-63, 67-68 (2018). See also Bundesgericht [BGer] [Federal Supreme Court] Nov. 26, 2015, 142 ENTSCHEIDUNGEN DES SCHWEIZERISCHEN BUNDESGERICHTS [BGE] II 35 (Switz.).

${ }^{95} \mathrm{See}$ Bundesgericht [BGer] [Federal Supreme Court] Oct. 12, 2012, 139 ENTSCHEIDUNGEN DES SCHWEIZERISCHEN BundESGERICHTS [BGE] I 16 para. 3.2 (Switz.).

${ }^{96}$ See id. at para. 4.3.3.

${ }^{97}$ See id. at para. 4.3.4.

${ }^{98} \mathrm{See}$ id. at para. 4.3 .
} 
The Court also made an obiter dictum regarding the potential conflict between constitutional provisions and international human rights law. Even if the provision were directly applicable, the Court stated that it would not change the outcome of the case. ${ }^{99}$ The Court reasoned that Switzerland is a party to the ECHR. Consequently, it is obliged to undertake all the necessary measures to implement the judgments of the European Court of Human Rights (ECtHR) and to prevent violations of the Convention. ${ }^{100}$ The Court further added that it has decided not to apply Article 121(3) of the Constitution in light of this obligation. ${ }^{101}$

Helen Keller and Reto Walther have interpreted the Court's ruling as a statement that "the Convention would take precedence over a recently adopted, directly applicable constitutional provision." 102 Meanwhile, Rosalind Dixon and Felix Uhlmann considered the judgment a form of weak review, as the Court has relied on the non-self-executing nature of the amendment to defer the issue to the Federal Assembly. ${ }^{103}$ The judgment itself incurred the wrath of the Swiss People's Party who then proceeded to launch a popular initiative to assert the primacy of national law over international law, although the initiative was rejected by sixty-six percent of the voters in $2018 .^{104}$

Nevertheless, it would be premature to conclude based on this case alone that international human rights law, in general, has become an ex post facto limitation to popularly-enacted constitutional amendment. As noted by Dixon and Uhlmann, the Swiss Parliament could still override the Court's non-application of a constitutional amendment by adopting implementing legislation. ${ }^{105}$ Furthermore, with regard to the obiter dictum, the Court has stated that the obligation to comply with the ECHR would still stand even if the constitutional provision were directly applicable; the Court has not ruled that the former could overturn the latter, and the Court has also not assumed that it has the power to do so.

\section{Human Rights Limitation in Ireland?}

The Irish Constitution contains four provisions that are most often associated with the idea of "popular sovereignty." 106 First, the Preamble declares that "We, the people of Éire . . do hereby enact, adopt, and give ourselves this Constitution." 107 Second, Article 6.1 of the Constitution stresses that "[a]ll powers of government, legislative, executive and judicial, derive, under God, from the people, whose right it is to designate the rulers of the State and, in final appeal, to decide all questions of national policy, according to the requirements of the common good." 108 Third, Article 46.2 of the Constitution stipulates that all constitutional amendments that have been passed by the lower and upper house of the Oireachtas (Irish legislature) must be approved by the people through a referendum before it can come into force. ${ }^{109}$ Finally, Article 47 of the Constitution states that a proposed amendment would be successful if it has been approved by a majority of the votes cast at the referendum. ${ }^{110}$

\footnotetext{
${ }^{99}$ See id. at para. 5 .

${ }^{100}$ See id. at para. 5.2.3.

${ }^{101}$ See id. at para. 5.3 .

${ }^{102}$ Helen Keller \& Reto Walther, Resistance in Switzerland: Populist Rather Than Principled, in PRINCIPLED RESISTANCE TO ECtHR Judgments - A New Paradigm? 161, 186 (Marten Breuer ed., 2019).

${ }^{103}$ See Dixon \& Uhlmann, supra note 94 , at 68.

${ }^{104}$ See Keller \& Walther, supra note 102, at 187; see also BBL 20183497 (2018), https://www.fedlex.admin.ch/eli/fga/2018/ 1347/de; BBL 20195931 (2019), https://www.fedlex.admin.ch/eli/fga/2019/2139/de.

${ }^{105}$ See Dixon \& Uhlmann, supra note 94, at 57, 69.

${ }^{106}$ See Tom Hickey, Popular Sovereignty in Irish Constitutional Law, 40 Dublin UnIV. L. J. 147 (2017).

${ }^{107}$ CONSTITUTION OF IRELAND 1937 pmbl., https://www.irishstatutebook.ie/eli/cons/en/html.

${ }^{108}$ CONSTITUTION OF IRELAND 1937 art. 6.1, https://www.irishstatutebook.ie/eli/cons/en/html.

${ }^{109}$ See CONSTITUTION OF IRELAND 1937 art. 46.2, https://www.irishstatutebook.ie/eli/cons/en/html.

${ }^{110}$ See CONSTITUTION OF IRELAND 1937 art. 47.1, https://www.irishstatutebook.ie/eli/cons/en/html.
} 
At the same time, the Irish Constitution contains various references to natural law and Christianity. ${ }^{111}$ As an example, the Preamble of the Constitution proudly proclaims, "In the Name of the Most Holy Trinity, from Whom is all authority and to Whom," and the people of Ireland in the Preamble also acknowledge their obligations "to our Divine Lord, Jesus Christ." 112 Moreover, the fundamental rights provisions in the Constitution also often refer to "natural rights." Article 41.1, for instance, states that "[t]he State recognises the Family as the natural primary and fundamental unit group of Society, and as a moral institution possessing inalienable and imprescriptible rights, antecedent and superior to all positive law." 113 Similarly, Article 42A.1 enshrines that "[t]he State recognises and affirms the natural and imprescriptible rights of all children ...", while Article 43.1.1 reads, "[t]he State acknowledges that man, in virtue of his rational being, has the natural right, antecedent to positive law, to the private ownership of external goods." 114

At first glance, the use of adjectives such as "inalienable" and "superior" seems to imply that natural rights could take precedence over any form of positive law, including popularly-enacted constitutional amendments. ${ }^{115}$ Irish constitutional jurisprudence, however, still conceives the people as being paramount in the process of effectuating constitutional amendments. ${ }^{116}$ In Riordan $v$. An Taoiseach (No. 1), the constitutionality of the Fifteenth Amendment to the Constitution of Ireland was challenged. ${ }^{117}$ The Amendment was intended to remove the constitutional prohibition on divorce, and it was narrowly approved by 50.28 percent of the Irish electorate. The plaintiff in the case alleged that the original amendment bill was unconstitutional as it was "repugnant" to the former Article 41.3.20 of the Constitution that prohibited divorce. ${ }^{118}$ The Supreme Court disagreed and declared, "[t]here can be no question of a constitutional amendment properly placed before the people and approved by them being itself unconstitutional." 119 Furthermore, in Hanafin v. Minister for the Environment, concerning the allegation that the government sought to influence the outcome of the divorce referendum, the Supreme Court held that " $[t]$ he will of the people as expressed in a referendum providing for the amendment of the Constitution is sacrosanct and if freely given, cannot be interfered with. The decision

${ }^{111}$ See Aileen Kavanagh, Natural Law, Christian Values and the Ideal of Justice, 48 IrISH JurIST 71, 72-73 (2012); Declan Costello, The Natural Law and the Irish Constitution, 45 STUD.: IRISH Q. REV. 403 (1965); V. Bradley Lewis, Natural Law in Irish Constitutional Jurisprudence 2 CATH. Soc. SCI. ReV. 171, 173 (1997); Aisling O’Sullivan \& PWC Chan, Judicial Review in Ireland and the Relationship Between the Irish Constitution and Natural Law, 15 NotTingHAM L.J. 18, 25-29 (2006); Eoin Carolan, The Evolution of Natural Law in Ireland, in The Invisible Constitution in Comparative Perspective 431,431 (Rosalind Dixon \& Adrienne Stone eds., 2018).

${ }^{112}$ CONSTITUTION OF IRELAND 1937 pmbl., https://www.irishstatutebook.ie/eli/cons/en/html.

${ }^{113}$ CONSTITUTION OF IRELAND 1937 art. 41.1, https://www.irishstatutebook.ie/eli/cons/en/html (emphasis added).

${ }^{114}$ CONSTITUTION OF IRELAND 1937 art. 42A.1, 43.1.1, https://www.irishstatutebook.ie/eli/cons/en/html (emphasis added). Furthermore, in Irish constitutional jurisprudence, there is the doctrine of "unenumerated rights" that are based on Article 40.3 of the Constitution. The Justices of the Supreme Court inferred the existence of unenumerated rights based on external sources such as natural law or, more recently, international human rights law. See generally James Rooney, International Human Rights as a Source of Unenumerated Rights: Lessons from the Natural Law, 41 DUBLIN UNIV. LAW L.J. 141 (2019); Oran Doyle, Legal Positivism, Natural Law and the Constitution, 31 Dublin UnIV. LAW L.J. 206 (2009); Carolan, supra note 111, at 434-37, 440-53; David Kenny, Recent Developments in the Right of the Person in Article 40.3: Fleming $v$ Ireland and the Spectre of Unenumerated Rights, 36 Dublin UnIV. LaW L.J. 322, 328-31 (2013).

${ }^{115}$ See Roderick O'Hanlon, Natural Rights and the Irish Constitution, 11 IrISH L. Times 8, 9-10 (1993). See also Diarmuid Rossa Phelan, Natural Law and Popular Sovereignty: The Irish Legal Order, 86 STUD.: IRISH Q. ReV. 215, 217-18 (1997); Rooney, supra note 114 (arguing that the doctrine of unenumerated rights has been used by the Supreme Court to gradually expand its power of rights review and concluding that " $[\mathrm{t}]$ he Court had reached a point where ... it could have, with strong precedential authority, overrode the decision of the People to amend the Constitution.").

${ }^{116}$ See Eoin Daly, Translating Popular Sovereignty as Unfettered Constitutional Amendability, 15 EUR. CONST. L. REV. 619, 625 (2019); O'Sullivan \& Chan, supra note 111, at 30; Colm O'Cinneide, “The People Are the Masters": The Paradox of Constitutionalism and the Status of Sovereignty, 48 IRISH JURIST 249, 251 (2012); Carolan, supra note 111, at 438-39.

${ }^{117}$ See Riordan v. An Taoiseach [1999] IESC 1 [1999] 4 IR 343 (Ir.).

${ }^{118}$ See id. at para. 7.

${ }^{119} \mathrm{Id}$. at para. 9 . 
is theirs and theirs alone." 120 This is despite the formulation of Article 41.1 of the Constitution, which indicates that the principles of the family are antecedent and superior to positive law. ${ }^{121}$

Furthermore, the Irish Supreme Court has officially held that any reference to "natural law" could not set aside the judgment of the people as sovereign. In the Abortion Information case, the validity of the Fourteenth Amendment to the Constitution of Ireland was contested, as it would allow citizens to obtain or make available abortion information that is lawfully available in another state. ${ }^{122}$ This was deemed to be contrary to the former Article $40.3 .3^{\circ}$ of the Constitution that protected "the right to life of the unborn." 123 The counsel representing the right to life of the unborn held that " $[\mathrm{t}]$ he Court is obliged to take into account the natural law. The vox populi cannot be the decisive arbiter of what is right and wrong." ${ }^{24}$ Consequently, in the counsel's view, "no provision of the Constitution or of any Act enacted by the Legislature or any judicial interpretation thereof can be contrary to Natural Law, and if it is, cannot be enforced." 125 The Supreme Court is not convinced with this argument. Instead, it declared that " $[t]$ he People were entitled to amend the Constitution in accordance with the provisions of Article 46 of the Constitution and the Constitution as so amended by the Fourteenth Amendment is the fundamental and supreme law of the State representing as it does the will of the People." ${ }^{126}$ It is also worth noting that in 2018, with the blessing of 66.4 percent of the electorate, Article $40.3 .3^{\circ}$ was replaced with a text allowing the Oireachtas to regulate abortion. ${ }^{127}$

\section{Sovereignty and Constitutional Referendum}

Popular sovereignty has become the cornerstone of modern constitutional law. "Sovereignty," however, is not a monolithic concept. As argued by Andreas Kalyvas, there is no single exclusive concept of sovereignty. ${ }^{128}$ With this observation as a starting point, this Section will scrutinize three sovereignty concepts that have been used to explain and justify the source of authority behind a constitutional referendum, namely command, constituent, and constituted sovereignty. Subsequently, it will construct a theoretical framework based on a synthesis of constituent and constituted sovereignty.

\section{Command and Constituent Sovereignty}

Kalyvas argued that the concept of "sovereignty" had been historically defined in two ways, namely "command" and "constituent" sovereignty. The former is an absolutist concept that could be traced back to the Roman title imperator (emperor), whose power of absolute command has become identical to the sovereign. ${ }^{129}$ This would later be reflected in the writings of Jean Bodin, who wrote that sovereignty is "the most high, absolute, and perpetual power," 130 and other classical legal theorists such as Thomas Hobbes. ${ }^{131}$ Christopher W. Morris called this model

\footnotetext{
${ }^{120}$ Hanafin v. Minister for the Env't [1996] IESC 6 [1996] 2 ILRM 61 (H. Ct.) (Ir.).

${ }^{121}$ See Daly, supra note 116 , at 625.

${ }^{122}$ In re Article 26 of the Const. \& Regul. Info. , 1995 [1995] 1 IR 1 (Ir.) (Abortion Information Case).

${ }^{123} I d$. at 37.

${ }^{124} I d$. at 10 .

${ }^{125} \mathrm{Id}$. at 38 .

${ }^{126} I d$. at 43

${ }^{127}$ See Thirty-sixth Amendment of the Constitution Act 2018 (Irish Statute Book) http://www.irishstatutebook.ie/eli/2018/ ca/36/enacted/en/print (last visited Aug. 30, 2020).

${ }^{128}$ Andreas Kalyvas, Popular Sovereignty, Democracy, and the Constituent Power, 12 Constellations 223, 225 (2005). See also Lars Vinx, The Incoherence of Strong Popular Sovereignty, 11 INT'L J. Const. L. 101 (2013).

${ }^{129}$ Kalyvas, supra note 128 , at 224.

${ }^{130}$ Jean Bodin, The Six Bookes of a Commonweale 84 (Richard Knolles trans., Kenneth Douglas McRae ed., 1962); Id. at 224.

${ }^{131}$ Thomas Hobbes, LeViathan ch. 22 (1985).
} 
"the classical view," according to which sovereignty is considered as "the highest, final and supreme political and legal authority (and power) within the territorially defined domain of a system of direct rule."132

Within this context, Kalyvas presented "constituent sovereignty" as an alternative conceptualization. ${ }^{133} \mathrm{He}$ first defined the "sovereign" as the one who "determines the constitutional form, the juridical and political identity, and the governmental structure of a community in its entirety." ${ }^{34}$ Kalyvas then identified two fundamental traits of constituent sovereignty. First, under "constituent sovereignty," the sovereign is involved in the creative undertaking of establishing a new constitutional order. It does not rule but rather legislates higher legal norms; it is not repressive but rather productive. ${ }^{135}$ In other words, the sovereign, in this sense, possesses constituent power. ${ }^{136}$ Second, the constituent sovereign always precedes the constitutional order that it creates. ${ }^{137}$ Therefore, the constituent sovereign could be considered a sort of prime mover (primum movens), as Kalyvas argued that it could not be traced back to another source of authority before it. Otherwise, Kalyvas argued that the constituent power of the sovereign would rather be constituted; the simultaneous existence of both elements is a logical impossibility in his view. ${ }^{138}$ Based on this elaboration, Stephen Tierney concluded that under the concept of constituent sovereignty, the sovereign has become "the source of the constitution and of its authority." 139

How can these concepts explain the source of authority behind constitutional referendums? Tierney held that a constitutional referendum is a way for the people as sovereign to shape higher legal norms, define the constitutional identity of a nation, or even create an entirely new constitutional order. ${ }^{140}$ Tierney then made a distinction between "internal constitutional referendum" that "operates wholly within constitutional structures" and "external constitutional referendum" that is "deployed in the creation of new constitutions or new states." 141 Tierney argued that the constituent sovereignty model more aptly encapsulates "external constitutional referendum" or "constitution-framing referendum" given that the people can be demonstrated as having a constituting role by establishing a new constitutional order. ${ }^{142}$ Simultaneously, Tierney claimed that the command sovereignty model better conceptualizes "internal constitutional referendum" or "constitution-changing referendum." 143 Tierney reasoned that although the people in this arrangement are involved in producing a new constitutional law, their role is not constitutive. Moreover, the referendum itself is regulated by an existing constitution and is taking place within the same constitutional order. ${ }^{144}$ In other words, "the people" here do not precede the constitutional order; "the people" in an internal constitutional referendum rule as an absolute and final arbiter within a certain existing constitutional order, and yet they do not establish the order itself.

\footnotetext{
${ }^{132}$ Christopher Morris, The Very Idea of Popular Sovereignty, 17 Soc. PHIL. \& POL'Y 1, 5 (2000).

${ }^{133}$ Kalyvas, supra note 128 , at $225,227$.

${ }^{134}$ Id. at 226.

${ }^{135} \mathrm{Id}$. at $226-27$.

${ }^{136}$ See Yaniv RoznaI, "We the People", "Oui the People" and the Collective Body: Perceptions of Constituent Power, in Comparative Constitutional Theory 295, 295 (Gary J. Jacobsohn \& Miguel Schor eds., 2018).

${ }^{137}$ Kalyvas, supra note 128 , at $227-28$.

${ }^{138} \mathrm{Id}$. at 228 .

${ }^{139}$ Stephen Tierney, Constitutional Referendums: A Theoretical Inquiry, 72 MoD. L. REv. 360, 363 (2009).

${ }^{140} I d$. at 362-64. See also Luigi Corrias, Populism in a Constitutional Key: Constituent Power, Popular Sovereignty and Constitutional Identity, 12 Eur. Const. L. Rev. 6, 10-13 (2016).

${ }^{141}$ Stephen Tierney, Constitutional Referendums: The Theory and Practice of Republican Deliberation 11 (2012).

${ }^{142} I d$. at $12-13$.

${ }^{143} \mathrm{Id}$. at 12 .

${ }^{144} I d$. at 12 .
} 


\section{Constituted Sovereignty}

The applicability of the "constituent sovereignty" concept to a constitutional referendum has been subject to serious criticism. Eoin Daly argued that such an idea "overlooks the degree to which popular power is constrained or pre-constituted within the constitutional-referendum process." 145 Even if a constitutional referendum were assumed to be the manifestation of the will of the people as the constituent sovereign, such an assumption would imply that "the people" are equal to eligible voters. However, as demonstrated by János Kis, "the existence of a 'people"” in this sense presupposes the existence of a constitution that determines who of all the inhabitants of the country is to have the right to vote and what that right is to include." ${ }^{146}$ Thus, Kis concluded that such a constitution "cannot originate in the "people"- to the contrary, the "people" originate in the constitution. ${ }^{147}$

Daly furthermore stated that the idea of constituent popular sovereignty is "empirically and sociologically unfounded." 148 "The people" are regarded as being too abstract and diverse to express what they want clearly. ${ }^{149}$ In this respect, Hans Kelsen observed that the people are "[s]plit by national, religious, and economic conflicts," and their supposed unity is "more a bundle of groups than a coherent mass of one and the same aggregate state. Only in a normative sense can one speak of a unity." ${ }^{\prime 50}$ In a similar vein, Simone Chambers observed that:

The 'people' as constituent authority can never be synonymous with the people as an empirical entity. The 'people' as a purely empirical entity is never unanimous and always leads to a situation in which there is a 'we the people' who won versus a 'we the people' who lost. ${ }^{151}$

Without the possibility of pinning down their will, "the people" would always require representation. ${ }^{152}$ Constitutional documents are usually drafted by a few specialists, such as lawyers and politicians, rather than "the people" themselves. ${ }^{153}$ With regard to the issue of the initiator of the referendum, the subject matter was not brought by "the people" in the unitary sense, but rather the initiating authority such as the parliament. ${ }^{154}$ In the words of Patrick Taillon, these representatives are "in a superior position in relation to other citizens, who remain limited to playing the passive role of approving or rejecting a plan designed by others." ${ }^{155}$ Even when referendums may be called through popular initiatives, despite the requirement to fulfill a minimum electoral threshold, the proposal was authored by a certain group or movement instead of the people as a whole. ${ }^{156}$ Based

\footnotetext{
${ }^{145}$ See Daly, supra note 116, at 628. See also Joel Colón-Ríos, The Legitimacy of the Juridical: Constituent Power, Democracy, and the Limits of Constitutional Reform, 48 Osgoode HaLl L. J. 199, 235-36 (2010).

${ }^{146}$ János Kis, Constitutional Democracy 135 (2003).

${ }^{147} I d$. See also David Dyzenhaus, Constitutionalism in an Old Key: Legality and Constituent Power, 1 GLOB. Constitutionalism 229, 233-34 (2012).

${ }^{148}$ Daly, supra note 116 , at 628 .

${ }^{149}$ Hickey, supra note 106; Kis, supra note 146, at 136; Id. at 631-32; Eoin Daly, A Republican Defence of the Constitutional Referendum, 35 LEGAL STUD. 30, 39 (2013).

${ }^{150}$ Hans Kelsen, On the Essence and Value of Democracy, in WeIMAR: A JURISPRUDENCE OF CRISIS 84, 90 (Arthur J. Jacobson \& Bernhard Schlink eds., 2000).

${ }^{151}$ Simone Chambers, Democracy, Popular Sovereignty, and Constitutional Legitimacy, 11 Constellations 153, 169 (2004).

${ }^{152}$ Yaniv Roznai, Amendment Power, Constituent Power, and Popular Sovereignty: Linking Unamendability and Amendment Procedures, in The Foundations and Traditions of Constitutional Amendment 23, 27 (Richard Albert, Xenophon Contiades, \& Alkmene Fotiadou eds., 2017); Roznai, supra note 136, at 303; Denis J. Galligan, The Sovereignty Deficit of Modern Constitutions, 33 Oxford J. Legal STUD. 703, 713 (2013); Richard Kay, Constituent Authority, 59 Aм. J. COMPAR. L. 715, 739, 747 (2011).

${ }^{153}$ See Daly, supra note 116 , at 629 ; Daly, supra note 149 , at 40 . See also Morris, supra note 132 , at 8.

${ }^{154}$ Daly, supra note 149 , at 39.

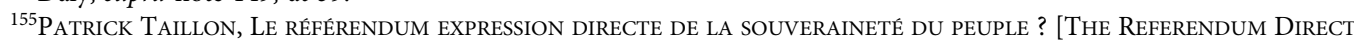
EXPression of the Sovereignty of THE PeOple?] 173 (2012).

${ }^{156}$ Daly, supra note 149 , at 39; Daly, supra note 116 , at 632.
} 
on these sorts of arguments, Daly asserted that the role of the people in a constitutional referendum could only be authorizing rather than authorial, reactive rather than creative. ${ }^{157}$ They do not directly control the formulation and modification of a new constitutional role; they simply respond by approving or rejecting it.

One might retort this point by stating that Iceland experimented with a very inclusive method of constitutional drafting from 2010 through 2013. Instead of the classical image of "founding fathers" wearing fancy suits in an ornate building, the constitutional council who was tasked with the drafting consisted of twenty-five members who had no prior political experience. They were elected out of 522 individuals who ran for the position. The composition had a relative gender balance of ten women and fifteen men, while their background was wide-ranging from a doctor to a farmer, a student, and a disability rights activist. They regularly sought popular input on the internet. Furthermore, the entire process also involved a National Forum of 950 demographicallyrepresentative citizens to gain feedback on the principles and values that should be enshrined in the Constitution. Eventually, the resulting draft was presented to the public in a non-binding referendum in October, 2012, and it was approved by two-thirds of the electorate. The draft itself eventually stalled in the Parliament, and it was never promulgated. ${ }^{158}$

The Icelandic could perhaps be used as an illustration that "the people" could become more involved in a constitutional change process. Nevertheless, it still does not remove Daly's criticism that "the people" are too abstract of a category to be able to express its will clearly. Even in the relatively homogenous country of Iceland, where the population is only around 360,000, the process still requires representation in the form of a constitutional council. "The people" also have diverse conflicting interests that might not be entirely represented by the council; as an illustration, Hélène Landemore suspected that one of the factors that led to the failure of the draft in the Icelandic Parliament was lobbying from fishermen who opposed a provision declaring that natural resources that are not privately owned would become the property of the state. ${ }^{159}$

Based on the view that the role of "the people" is reactive, Daly argued that the people are better considered as constituted, as an "ad hoc constitutional legislature with negative legislative powers." ${ }^{60}$ He subsequently concluded that constitutional referendums are more aptly perceived as "a checking mechanism by which the people exercise some measure of influence or control over the powers of intermediary bodies, executive and legislative, in the domain of constitutional change." ${ }^{61}$ In this manner, Daly has formulated a concept of "constituted sovereignty" that is more in line with the constitutional practice of referendums. ${ }^{162}$

Daly further developed his concept of "constituted sovereignty" by arguing that sovereignty means "unaccountability" in the sense that the sovereign's judgment "cannot be overturned by any authority, whether judicial or otherwise." 163 Thus, in his view, the people can be considered as a sovereign within the framework of internal constitutional referendum because of their role "at the end point of constitutional change rather than at its inception ... they are designated as a locus of final authority within the constitutional order of the state." 164

At first glance, the "constituted sovereignty" concept might resemble the "command sovereignty" model, as the sovereign in these concepts is acting within an existing constitutional order, and their final judgment is indisputable. Nevertheless, Daly emphasized that the idea of

\footnotetext{
${ }^{157}$ See Daly, supra note 116, at 630-32; Daly, supra note 149, at 39-41. See also Roznai, supra note 136, at 304.

${ }^{158}$ Hélène Landemore, Inclusive Constitution-Making: The Icelandic Experiment, 23 J. POL. PHIL. 166 (2015).

${ }^{159} \mathrm{Id}$. at 170 .

${ }^{160}$ See Daly, supra note 116, at 632; Daly, supra note 149, at 40-41; Eoin Daly, Republican Themes in the Irish Constitutional Tradition, 41 ÉTUDES IRLANDAISES 163, 172-73 (2016). See also Roznai, supra note 12, at 170 (observing that the role of the people in a referendum could be as "a constitutional organ").

${ }^{161}$ Daly, supra note 116, at 632-33; see also Daly, supra note 149 , at 39-40.

${ }^{162} \mathrm{Cf}$. Taillon, supra note 155 , at 487 (explaining the conception of "sovereignty within the constitution").

${ }^{163}$ Daly, supra note 116, at 633.

${ }^{164} I d$. at 635 .
} 
"unaccountability" is to be distinguished from "supremacy" or "omnipotence" in the Hobbesian sense, given that modern states "lack a single pinnacle of authority," and the unaccountability itself operates within a "limited jurisdiction of constitutional amendment." 165 Based on this observation, Daly concluded that:

Sovereignty can be dissociated from "command" because, given the inevitably divided and dispersed nature of the decisional process_-rendering impossible any single apex of authority - sovereignty, then, is expressed not in a crude idea of supremacy as such but rather in the finality and unaccountability of the sovereign's judgment. ${ }^{166}$

In constitutional law terms, Daly also added that this unaccountability principle is "most likely to be translated as a principle of non-justiciability of popularly effected constitutional amendments."167

\section{Constituent-Constituted Duality}

A constitutional referendum can be conceptualized as an exercise of "constituted sovereignty." Yet, most modern constitutions still appeal to "the people" as a direct source of legitimacy through the declaration, "We the People." 68 Article 5 of the Ukrainian Constitution, for instance, reads " $[\mathrm{t}]$ he people are the bearers of sovereignty and the only source of power in Ukraine."169 Article 347 of the 1999 Venezuelan Constitution even declares that "[t]he original constituent power rests with the people of Venezuela." ${ }^{770}$ While such provisions should only be considered as recognitive instead of constitutive, ${ }^{171}$ they demonstrate how the concept of constituent sovereignty cannot simply be dismissed irrespective of its deficiencies.

In fact, "the people as the constituent sovereign" should not be seen as a historical description of the state's establishment. ${ }^{172}$ Historian F.H. Hinsley held that historically the state always precedes the concept of sovereignty, and the former has ruled over a community without the latter. ${ }^{173}$ Over time, when the community had become conscious of the state and had also sufficiently recognized the state's rule, the concept of sovereignty would be coined to justify the rule. ${ }^{174}$ Hinsley then argued that the function of sovereignty has always been "either to strengthen the claims of power or to strengthen the ways by which political power may be called to account." 175

Based on this historical observation, it might not be relevant whether the concept of constituent sovereignty is empirically unfounded; what matters is that modern constitutional practice widely appeals to such a symbolism to legitimize the rule and the existence of the state itself. ${ }^{176}$ Taillon also argued that the concept of "sovereignty above the constitution" is "more a principled

\footnotetext{
${ }^{165} \mathrm{Id}$. at 634 .

${ }^{166} \mathrm{Id}$. at $637-38$

${ }^{167} \mathrm{Id}$. at 640 .

${ }^{168}$ Simone Chambers, Constitutional Referendums and Democratic Deliberation, in ReFERENDUm DemocracY: CitizENS, Elites and Deliberation in Referendum Campaigns 231, 237 (Matthew Mendelsohn \& Andrew Parkin eds., 2001). See also Andrew G. I. Kilberg, We the People: The Original Meaning of Popular Sovereignty, 100 VA. L. ReV. 1061 (2014).

${ }^{169}$ КОНСТИТУція УКРАÏнИ [CONSTITUTION OF UKRAINE] June 28, 1996, art. 5 (amended 2016).

${ }^{170}$ Constitución de la República Bolivariana de Venezuela [Constitution of the Bolivarian Republic of VenEZUELA] Dec. 19, 1999, art. 347.

${ }^{171}$ Roznai, supra note 12 , at 166.

${ }^{172}$ Margaret Canovan, The People 122-38 (2005); Chambers, supra note 151, at 154-55.

${ }^{173}$ F.H. HiNSLEY, SOVEREIGNTY 17 (2d ed. 1986).

${ }^{174} I d$. at 21 .

${ }^{175} \mathrm{Id}$. at 25 .

${ }^{176}$ Bernard Yack, Popular Sovereignty and Nationalism, 29 POL. THeORY 517, 522 (2001); Taillon, supra note 155, at 487. See also O'Cinneide, supra note 116, at 256; Kay, supra note 152, at 753-55; Roznai, supra note 136, at 306-08, 315-16.
} 
postulate rather than a practical reality," 177 while Roznai considered the idea of "the people" constituting the constitution for themselves as "a myth, a fiction." 178 Even though the people might not have actually written the constitution themselves, "the people" are still conceived as the sovereign so that the constitution could be attributed to a single act of will. ${ }^{179}$ Roznai further added that such an idea explains the "source" of political authority rather than "its mode of exercise." 180

In this way, the symbolism of "the people as the constituent sovereign" is a form of "transcendent sovereignty." As argued by Lior Barshack, "transcendent" implies that sovereignty is vested in an "immortal," "imaginary," and "collective" entity that "retains its identity through past, present, and future generations." 181 This is to be distinguished from "immanent sovereignty" exercised by the living, such as "the people" in the present generation. ${ }^{182}$

Thus, I argue that there is a distinction between "the constituent people," which is mythical, and "the constituted people," which is empiric. The former refers to what Margaret Canovan described as "something collective, abstract, dignified and mysterious: an entity . . . that has a continuous existence or history, transcending and outliving its individual members." 183 The constituent people exist extra-constitutionally, and they are not bound by the constitution that they mythically create. Furthermore, their power does not emanate from any other source; in other words, they are the ultimate authority. Meanwhile, the latter corresponds to individuals of the present generation, which Canovan calls "a collection of ordinary, ever-changing people with their separate lives, interests and views." 184 The constituted people, however, have a more specific scope; the term refers to individuals of the present generation who are endowed with the right to vote. Their role as an unaccountable legislator is always conferred by the constitution, and the criteria for determining those who may vote in a referendum are also determined by the very same constitution or electoral laws emanating from that constitution. Consequently, the constituted people in this setting will de facto be one of the constitutional organs of the state. ${ }^{185}$

Once "the constituent people" fulfilled their role as a source of authority for constituting a new legal order, they will remain in the background, unconstrained by the constitutional order that has just been established. ${ }^{186}$ "The constituted people" in the present generation can re-enact the founding myth of "the people as the constituent" through the mechanism of a constitutional referendum. In this regard, the purpose of a constitutional referendum will be to "bridge the gap between the imaginary people and the real people." 187

Building on the theory of constituent and constituted sovereignty, I do not view them in a binary manner. Instead, I argue that both of them are applicable simultaneously in the context of a popularly-enacted constitutional amendment. ${ }^{188}$ In quantum physics, matter can be described either as a particle or a wave despite the counter-intuitiveness of such a duality; this idea is

\footnotetext{
${ }^{177}$ See Taillon, supra note 155, at 486. See also Kay, supra note 152, at 760 ("The people is always an artifice with some more or less convincing tie to the actual political wishes of some number of human beings at the time of constitution-making.”).

${ }^{178}$ Roznai, supra note 152, at 27; Roznai, supra note 136, at 304. See also Canovan, supra note 172, at 131-32 (preferring to use the term "myth" instead of "fiction", because the latter has the connotation of being a "deliberate invention by a particular agent or agents at a particular time and place." Consequently, it could lead to suspicions that the fiction constitutes a "deception" to boost the legitimacy of rulers. Meanwhile, the term "myth" is more nuanced given that it suggests "a product of collective imagination over time rather than a deliberate and specific invention").

${ }^{179}$ Roznai, supra note 152 , at $26-27$.

${ }^{180}$ Roznai, supra note 136 , at 304 .

${ }^{181}$ Lior Barshack, Time and the Constitution, 7 INT'L J. CONST. L. 553, 554 (2009).

${ }^{182} \mathrm{Id}$. at 553 .

${ }^{183}$ Canovan, supra note 172 , at 6 .

${ }^{184} I d$.

${ }^{185}$ Daly, supra note 116, at 632. See also Roznai, supra note 12, at 170; Claude Klein, Is There a Need for an Amending Power Theory?, 13 IsR. L. REv. 203, 213-14 (1978).

${ }^{186}$ Roznai, supra note 12, at 110; Taillon, supra note 155 , at 493-94.

${ }^{187}$ Roznai, supra note 152 , at 25 ; Roznai, supra note 136 , at 311.

${ }^{188} \mathrm{Cf}$. Roznai, supra note 12, at 162 (arguing that constitutional systems are "polymorphic").
} 
commonly known as "wave-particle duality." 189 Similarly, a state can adhere to the legal fiction of "the people as the constituent sovereign," where there is the myth of "the people" as an authorial agent preceding the constitution. At the same time, the role of "the people" in that state can be described as de facto constituted. I will refer to this simultaneous applicability as the "constituentconstituted duality."

Through the lens of this duality, a constitutional referendum can be described as an amendment procedure imitating or resembling the moment when "the people" as the mythical constituent sovereign exercised its creative role. ${ }^{190}$ In the words of Roznai, "[t]hey attempt to create a constitutional moment." ${ }^{191}$ In this way, "the myth of 'the people' as holders of constituent power serves as the guiding narrative for constitutional design," 192 and it will become a direct source of legitimacy for the process of constitutional making and changing. Simultaneously, a referendum can be conceptualized through Daly's "constituted sovereignty," according to which the empiric people have become a final and unaccountable "ad hoc constitutional legislature with negative legislative power."193

The incorporation of the concept of "constituted sovereignty" into the duality could be subject to criticism. Daly basically has conceived that there is sovereignty within a constitutional order in the form of the unaccountability of the empiric people. Such a line of thought was criticized by Olivier Beaud back in 1994. He asserted that there could be no "sovereign within the constitution" because "constituent power is the only sovereign and constituted powers are not sovereign. The latter are constitutional magistrates of public power subject to the constitution."194

Nevertheless, this criticism is only relevant if we apply the concept of constituted sovereignty to constituted powers that are not "the people" themselves, such as the parliament or the executive, while at the same time subscribing to the idea of the people as the sovereign. The difference with the constituted people is that they are not an entirely distinct organ but rather connected to the constituent people in a dyophysite manner, meaning that "the people" have dual natures, namely "the constituent people" and "the constituted people." It should be noted, however, that "the people" are not miaphysite. This term is used if and only if the constituent people and the constituted people are united in one nature without any division or separation. Instead, under the dyophysite understanding, there are two separate natures that cannot be conflated with each other, and yet they both are still considered as "the people." Therefore, in the constituent-constituted duality, both constituent and constituted sovereignty are simply corollaries of popular sovereignty; in other words, they emanate from applying the concept of sovereignty to "the people."

\section{Limitation to Popularly-Enacted Constitutional Amendment?}

Does the application of constituent-constituted duality to constitutional referendum imply that the constituted people have an unfettered license to pass a constitutional amendment contrary to human rights? This Section will argue that from the perspective of constituted sovereignty, the only legitimate form of limitation to a popularly-enacted constitutional amendment is an ex ante limitation for the constituted people. It will also explore possible arguments to underpin an ex post facto limitation, and eventually conclude that such a limitation remains problematic from the perspective of popular sovereignty.

\footnotetext{
${ }^{189}$ Stephen Hawking \& Leonard Mlodinow, The Grand Design 58 (2010).

${ }^{190}$ Roznai, supra note 12 , at 169 .

${ }^{191}$ Id.

${ }^{192} \mathrm{Id}$.

${ }^{193}$ Daly, supra note 116 , at 632 . See also Roznai, supra note 12 , at 160-61.

${ }^{194}$ Olivier Beaud, La puissance de l'État [The Power of the State] 438 (1994).
} 


\section{Limitation to the Constituted People?}

Section C. established a clear distinction between "the constituent people" and "the constituted people," with the former escaping any effort of limitation by the constitution that it creates. As for the latter, there might be a ground to argue in favor of human rights limitation by the very same constitution. After all, without the constitution providing for a constitutional referendum and determining who is eligible to cast their unaccountable judgment, the constituted people will not be able to express themselves.

Under the concept of constituent-constituted duality, however, the constituted people are endowed with constituted sovereignty. Unlike the concept of power, sovereignty is presupposed to be one, indivisible and inalienable. ${ }^{195}$ János Kis's argument is elucidating in this regard:

The sovereign is an instance of that which gives instructions or rules to others yet does not receive instructions or rules from others; it is that which authorizes others yet whose power does not originate in authorization by others. For the sovereign's authority to be legitimate it must display some such characteristic that may justify why the series of authorizations may come to an end at it. Thus, the sovereign's legitimacy must be substantive rather than formal."196

Consequently, as Taillon put it, "material limits invokable against decisions taken by the people remain inconceivable from a democratic perspective based on the primacy or the sovereignty of the popular will."197

Similar with the constituent-constituted duality, Taillon also proposed two forms of popular sovereignty, namely, "sovereignty above the constitution" that is analogous to constituent sovereignty and "sovereignty within the constitutional framework" analogous to constituted sovereignty. ${ }^{198}$ Material limitation towards a referendum, in his view, is a form of "desacralization" that "contributes . . . towards the erosion of sovereignty within the state". ${ }^{199}$ He then argued that "although the people are often incapable of expressing themselves as sovereign power within a constitutional order, constitutional law nevertheless is incapable of completely preventing the expression of the sovereignty of the 'original constituent' people." ${ }^{200}$ Thus, in his view, sovereignty above the constitution can appear "at any time 'outside' the law" and therefore "undermine the effectivity" of limitation efforts. ${ }^{201}$ In other words, by virtue of sovereignty above the constitution, "the people" always have the "capacity to act 'outside' of the legal framework and to break free of the limit placed by law." 202 In this way, a referendum could be used "to erase the initial illegality of a revolutionary act." 203

Roznai further cemented the idea of the constituent people re-emerging to overcome limitations based on the view that the constituted people's involvement in a constitutional referendum serves as a "legitimation elevator" that will enhance the democratic legitimacy of the constitutional change process. ${ }^{204}$ Roznai then argued that constitutional amendment process should be inclusive, participatory, and deliberative to ensure that the involvement of the people would be "throughout the constitutional norms-creating process." ${ }^{205}$ The more this is ensured, the more we can claim

\footnotetext{
${ }^{195}$ See Taillon, supra note 155 , at $485,491$.

${ }^{196}$ Kis, supra note 146, at 134.

${ }^{197}$ Taillon, supra note 155 , at 551.

${ }^{198} \mathrm{Id}$. at $486-87$.

${ }^{199} \mathrm{Id}$. at 579 .

${ }^{200} I d$.

${ }^{201} I d$.

${ }^{202} \mathrm{Id}$. at $579-80$.

${ }^{203}$ Id. at 580 .

${ }^{204}$ Roznai, supra note 12 , at $170-71$.

${ }^{205}$ Roznai, supra note 152 , at $30-31$.
} 
that the constituent people have re-emerged, ${ }^{206}$ and thus, the less the process is bound by limitations. ${ }^{207}$

Richard Albert has even formulated a stronger conclusion in the specific context of the existence of unamendable provisions in various constitutions. He defined the "direct sovereignty" of the people as the capacity of "acting of their own volition in their own name, unfettered by the bureaucratic and political hurdles that representative democracy presents. It is therefore the purest form of sovereignty imaginable, the very apex of constitutional legitimacy and legitimate authority." 208 He then asserted that constitutional entrenchment does not only "compromise" that sovereignty but also "extinguishes" it. ${ }^{209} \mathrm{He}$ reasoned that "[e]ntrenchment suppresses popular choice to the detriment of citizenship and narrows the range of possibilities that citizens envision for themselves and their state." ${ }^{210} \mathrm{He}$ has also evoked the image of "the people" being subjected to "constitutional handcuffs," "unable to escape their constitutional shackles." ${ }^{11}$ Consequently, from Albert's perspective, even an ex ante limitation in the form of constitutional entrenchment would not be in line with popular sovereignty, let alone an ex post facto limitation in the form of judicial review.

Nevertheless, as observed by Luc Wintgens, there is a difference between popular sovereignty "as the locus of power-no other power than the power of the people can bind the people-and the way of exercising that power." ${ }^{212} \mathrm{He}$ also held that "[t]he procedure of the exercise of power does not limit sovereignty, but it directs it in a specific way." ${ }^{213}$ Based on this observation, I will depart from Taillon, Roznai, and Albert by arguing that the exercise of constituted sovereignty is by nature constrained. As demonstrated in the previous Section, the unaccountability of the constituted people's judgment is confined to the endpoint of the constitutional amendment process, even if there is a mechanism for popular initiatives. Given that the constituted people's role is and can only be reactive and authorizing, the exercise of their constituted sovereignty is inevitably subject to "limitation of choice." In other words, the constituted people have no choice but to accept or reject a constitutional proposal submitted to them.

This limitation of choice also applies to the scenario when a constitutional referendum is called unconstitutionally to overcome a constitutional limitation. For instance, when Charles de Gaulle used a referendum to bypass a parliamentary amendment mechanism in the French Constitution, ${ }^{214}$ it was not the constituted people themselves who initiated the amendment and called the referendum; it was de Gaulle. While an inclusive, deliberative, and participatory process of constitutional change can enhance legitimacy, the constituted people are still limited to their passive role at the end of the process, and, as argued in the previous Section, they can never be conflated with the mythical constituent people.

Consequently, from a theoretical perspective, constituted sovereignty only leaves room for an ex ante human rights limitation. Not only is the limitation of choice inherent in the exercise of constituted sovereignty, but also preventive control of constitutional referendums merely directs such an exercise in a way that is human rights compliant. Irrespective of whether the ex ante human rights limitation is based on positive or natural rights, the constituted people still have the last word with regard to proposals that are eventually submitted to them. Therefore, if a constitution prescribed an ex ante natural or positive rights limitation to a constitutional

\footnotetext{
${ }^{206}$ Roznai, supra note 136 , at 312-13.

${ }^{207}$ See Roznai, supra note 12 , at 158.

${ }^{208}$ Richard Albert, Constitutional Handcuffs, 42 ARIZ. STATE L.J. 663, 676 (2010).

${ }^{209}$ Id. See also Richard Albert, Counterconstitutionalism, 31 DALHOUSIE L.J. 1, 50 (2008).

${ }^{210}$ Albert, supra note 208, at 677.

${ }^{211} \mathrm{Id}$. at $676-77$.

${ }^{212}$ Luc Wintgens, Sovereignty and Representation, 14 RATIO JURIS 272, 279 (2001).

${ }^{213} I d$.

${ }^{214}$ Daly, supra note 116, at 622-23; O'Cinneide, supra note 116, at 256.
} 
referendum, such an explicit limitation would not impugn the judgment of the constituted people as the final unaccountable arbiter in approving or rejecting a constitutional amendment.

The example of Switzerland demonstrates the possibility of an explicit ex ante human rights limitation. Because mandatory provisions of international law are now enshrined as an ex ante limitation to popular initiative proposals, Swiss constitutional law has managed to avoid the direct clash between the will of the constituted people and non-derogable human rights. In the two examples of popular initiatives that were explained in Section B., subsection II., the constituted people have not yet cast their judgment with regard to the specific issues at hand, and thus the existence of an ex ante human rights limitation has not led to the overturning of the constituted sovereign's judgment.

However, when the "for a sensible asylum policy" popular initiative was first launched in July 1992, an ex ante limitation based on mandatory provisions of international law was not yet provided in the constitution. This raises a question: if an ex ante limitation is permissible from the perspective of constituted sovereignty, does it imply that judges may infer the existence of an ex ante natural or positive rights limitation to popularly-enacted constitutional amendment even when the constitution itself does not enshrine such a limit? If we assess this question purely from the perspective of constituted sovereignty, the answer seems to be that judges who have done so have not usurped the constituted people. The reason is that inferred limitation does not directly oppose or negate the final judgment of the constituted people as pronounced in a constitutional referendum, and thus, constituted sovereignty itself is not being subverted. Although one might retort that an ex ante control by judges could pre-empt the potential will of the people, the constituted people are inevitably constrained to choose between the options that are brought forward to them-irrespective of whether the options were shaped by judges, the parliament, or initiators of popular initiative-, and consequently such a limitation is still in line with constituted sovereignty.

At the same time, this conclusion could have a serious institutional repercussion. With judges being able to effectively amend the constitution by inserting a human rights limitation based on their own preferred conception, such as the one based on natural rights or international human rights law, they could be accused of misusing human rights to expand their own power. As observed by Melissa Schwartzberg:

In the case of formally entrenched provisions, a constitutional court may strike down a proposed amendment in the presence of clear textual support for its illegitimacy: In other words, the presence of a textual standard provides at least some constraint on the court. A doctrine of implicit entrenchment, on the other hand, would give constitutional courts sweeping power to determine what are the essentially immutable features of a regime . . . ${ }^{215}$

Thus, to avoid this institutional consequence and enhance its legitimacy, an ex ante human rights limitation should be based on an explicit limitation clause in the constitution proclaiming that there shall be no constitutional referendum whose subject matter would lead to the abrogation or constraint of human rights. The enactment of the human rights limitation should also be conducted in the most deliberative, participatory, and inclusive manner possible, ${ }^{216}$ particularly in order to enable a constructive dialogue regarding whether human rights should be regarded as natural or positive rights and which particular rights should be considered as inviolable. The legitimacy of such a limitation would also be stronger if the limitation clause was approved by the constituted people themselves through a constitutional referendum.

\footnotetext{
${ }^{215}$ Melissa Schwartzberg, Democracy and Legal Change 15-16 (2007).

${ }^{216} \mathrm{Cf}$. Joel Colón-Ríos, Deliberative Democracy and the Doctrine of Unconstitutional Constitutional Amendments, in THE Cambridge Handbook of Deliberative Constitutionalism 271, 278-80 (Ron Levy, Hoi Kong, Graeme Orr, Jeff King eds., 2018).
} 
Still, once the constituted people have pronounced their unaccountable judgment, an ex post facto limitation will not be theoretically possible because, in such a scenario, the constituted people will have exercised their sovereignty. If a court decides to overturn the decision of the constituted people in the name of human rights, the constituted people will no longer be the constituted sovereign. Instead, it will be the court that will become the final arbiter in that particular constitutional order. Even if we imagine a scenario in which an ex post facto limitation is approved with a resounding yes in a constitutional referendum, this will still have the effect of negating the constituted sovereignty of the constituted people in favor of the judges exercising the review. As a result, an ex post facto limitation is contrary to popular sovereignty because the judges will have effectively usurped the constituted sovereignty of the constituted people.

\section{Ex Post Facto Natural Rights Limitation?}

At the same time, when it comes to human rights, one could claim that they carry a special weight compared to other legal norms and thus could become an ex post facto limitation towards popularly-enacted constitutional amendments. This claim can be founded on a natural law approach. If human rights are conceived as being reflective of natural, universal, and imprescriptible rights based on God, the universe, or reason, instead of mere positive rights, one may then argue that natural rights are applicable to all peoples without any exception by virtue of the claim that natural law is the ultimate source of authority. ${ }^{217}$ Based on this starting point, one could then contend that human rights should be considered supraconstitutional. ${ }^{218}$ If this supraconstitutionality claim were assumed to be valid, it would imply that a human rights limitation can constrain the constituted people without having to be explicitly provided in the constitution. Judges would be able to impose an ex post facto natural rights limitation and declare a popularly-enacted constitutional amendment unconstitutional for contravening natural rights irrespective of whether the constitution recognizes the existence of natural law.

However, the supra-constitutionality thesis has been heavily criticized by Kemal Gözler. He asserted that "[h]uman rights, as envisaged by the defenders of supra-constitutionality, have no juridical value because they are deprived of material existence." ${ }^{219}$ Furthermore, he attacked the concept of natural rights itself by expounding the view that "there is no universal and objective criteria which could distinguish 'that which is just' from 'that which is unjust'; and we cannot obtain such a criterion by observing nature." 220 He also observed that every defender of natural rights has their own idea of which rights would belong to that category. Thus, in his view, "it is completely impossible to establish the existence of the instrumentum in which there are supraconstitutional principles."221

Similar to Gözler, Lech Garlicki, and Zofia Garlicka have also found that natural law "lacks the systemic (comprehensive) nature," which implies that "[t]here are so many different (and sometimes conflicting) normative systems associated with natural law that it is very difficult to agree on its exact scope and content." 22 They have also argued that natural law "lacks precision"; what they meant by this is that "it is almost impossible to define their precise meaning, that is, to transform them into sufficiently clear rules that may be used as a norm of reference in the adjudication process." 223

\footnotetext{
${ }^{217}$ See Oran Doyle, Legal Validity: Reflections on the Irish Constitution, 25 Dublin UnI. L.J. 56, 61 (2003).

${ }^{218}$ Serge Arné, Existe-t-il des normes supra-constitutionnelles? [Do Supra-Constitutional Norms Exist?], 2 REVUE DU DROIT public 460, 469 (1993). See also Kemal GöZler, Le pouvoir de RÉvision CONSTITUtionnelle [The Power OF Constitutional Revision] 295-96, 304 (1995).

${ }^{219}$ Gözler, supra note 218 , at 307.

${ }^{220} \mathrm{Id}$. at 307.

${ }^{221} \mathrm{Id}$. at 311 .

${ }^{222}$ Lech Garlicki \& Zofia A. Garlicka, External Review of Constitutional Amendments? International Law as a Norm of Reference, 44 IsR. L. REV. 343, 356 (2011).

${ }^{223} I d$.
} 
As for the possible counterpoint that one could find natural law principles in the human personality, Gözler asserted that "juridical norm is a human creation" and that the so-called "supraconstitutional norms" are "laid down by the natural law authors themselves." ${ }^{24}$ For Gözler, this implies that natural law authors "have not only substituted the ordinary legislature, but also, thanks to the theory of supra-constitutionality, the original constituent power." 225 Thus, a natural law-based argument can also be considered a form of "usurpation" of sovereignty by the natural law authors or by judges who have relied on such a notion to set aside the judgment of the constituted people. As argued by Oran Doyle, "[t]he paradox is that of an agent of positive law (the judge) determining what is superior to positive law." 226

Based on these arguments, it will be difficult to use natural law to uphold the legitimacy of an ex post facto limitation on popularly-enacted constitutional amendment. While natural law can still be enshrined as an ex ante limitation to popularly-enacted constitutional amendments, from the standpoint of popular sovereignty, ex post facto limitation based on "natural law" remains unjustifiable because otherwise, it will usurp the constituted sovereignty of the people and transform it into "the constituted sovereignty of judges who interpret natural law."

Even if a jurisdiction enshrines natural law in its constitution, it does not automatically imply that the constituted people will be bound by it. The Irish example has demonstrated how the inalienable and superior character of human rights in the Constitution still cannot be invoked as an argument to limit constituted sovereignty in an ex post facto manner. Such a limitation would overturn the constituted people's sovereignty by subjecting it to the unaccountable command of natural law-or, more specifically, judges who interpret natural law. Thus, by ruling that popularly-enacted constitutional amendments cannot be limited by natural law ex post facto, the judges of the Irish Supreme Court have refrained from usurping the constituted sovereignty of the people.

\section{Ex Post Facto Limitation as a Corollary of Sovereignty?}

With regard to human rights limitation, one might also argue that such a form of limitation is concerned with the protection of basic rights, which are prerequisites for the constituted people to be able to express themselves freely, such as freedom of expression and freedom of association. ${ }^{227}$ In this regard, Richard Stacey has argued that the concept of "popular sovereignty" itself entails "commitments to the constitutional protection of civil and political rights" and "a commitment to equality," 228 as these are believed to be necessary for the people to be able to act collectively and exercise their sovereignty. ${ }^{229}$ The elimination of these rights is consequently claimed to be beyond the reach of not only the constituted powers but also the constituent people. ${ }^{230}$ Based on this

\footnotetext{
${ }^{224}$ Gözler, supra note 218, at 311. See also Margaret MacDonald, Natural Rights, 47 Proc. Aristotelian Soc'y 225, 238-39 (1946)

${ }^{225}$ Gözler, supra note 218, at 311. See also Kemal Gözler, Sur la validité des limites à la révision constitutionnelle déduites de l'esprit de la constitution [On the Validity of Limits to Constitutional Revision Deduced from the Spirit of the Constitution], 31 ANNALES DE LA FACULTÉ DE DROIT D'IsTANBUl 109, 121 (1997).

${ }^{226}$ Doyle, supra note 217, at 66. See also Kenny, supra note 114, at 329-30 (2013).

${ }^{227}$ See Richard Stacey, Constituent Power and Carl Schmitt's Theory of Constitution in Kenya's Constitution-Making Process, 9 INT'L J. Const. L. 587, 608-13 (2011); Colón-Ríos, supra note 145, at 217-18; Arif Bulkan, The Limits of Constitution (Re)making in the Commonwealth Caribbean: Towards the 'Perfect Nation', 2 CANADIAN J. Hum. RTs. 81, 111 (2013). Cf. Jürgen Habermas \& William Rehg, Constitutional Democracy: A Paradoxical Union of Contradictory Principles?, 29 POL. THEORY 766, 773-78 (2001); Walter Murphy, Merlin's Memory: The Past and Future Imperfect of the Once and Future Polity, in Responding to Imperfection: The Theory and Practice of Constitutional Amendment 163 (Sanford Levinson ed., 1995).

${ }^{228}$ Richard Stacey, Popular Sovereignty and Revolutionary Constitution-Making, in PhILOSOPHICAL FOUNDATIONS OF Constitutional Law 161, 164 (David Dyzenhaus \& Malcolm Thorburn eds., 2016).

${ }^{229} \mathrm{Id}$. at $174-75$.

${ }^{230} I d$. at 177; Stacey, supra note 227 , at 610 .
} 
argument, ex post facto natural or positive rights limitations to popularly-enacted constitutional amendment could be regarded as legitimate because they emanate directly from popular sovereignty itself in order to protect the sovereign from the risk of "sovereign autophagy"; that the constituted people may approve amendments that will negate or even extinguish their own constituted sovereignty. ${ }^{231}$

However, there may be disagreements regarding which sort of rights are considered "basic" that popularly-enacted constitutional amendment can be limited to protect that right. ${ }^{232}$ For instance, one might ask whether the right to property should be considered as a basic right that is needed to ensure that "the people" can express themselves without coercion. ${ }^{233}$ One might also ponder why Stacey's list should only be restricted to civil and political rights because the right to education may also be argued as essential to ensure that the constituted people are informed enough to make informed decisions. Stacey himself has admitted that "[d]eciding which questions are structurally basic, which issues of rights are fundamental to the legal-political order . . . are themselves things that we, the people, might reasonably disagree about." 234

Moreover, the exact content of these "basic" rights still needs to be interpreted. As observed by Po Jen Yap, "[j]udges do not uphold the rule of law in the abstract but have to apply sacrosanct constitutional rights to specific and particularized facts that come before them." ${ }^{235}$ In the process, disagreements over the appropriate conception of these rights might arise. ${ }^{236}$ As an illustration, if limitation based on "human dignity" is assumed to be necessary to protect popular sovereignty from sovereign autophagy, we might ask the same question as R. George Wright, "why an amendment must be unconstitutional if . . . it limits the protection or advancement of one conception of human dignity for the sake of some other equally plausible conception of human dignity." 237

Even if we surmise that judges should act as an ex post facto controller of constitutional amendments, Yap has argued that the supporter of this thesis must demonstrate why the judge's particular interpretation "in every concrete context would always be superior to the amending body's conception each time." ${ }^{238}$ This would be problematic in the context of a popularly-enacted constitutional amendment. As warned by Yap, an ex post facto invalidation of constitutional amendment would lead to the consequence that "the scope of the amending power is ultimately circumscribed by what a handful of judges might think constitutes its proper limits," and that "every constitutional amendment approved by the People ... may technically come under the pruning knife of the judges." 239

Based on this observation, Taillon has rightly observed that imposing human rights above the people would lead to "a mutation of the sovereignty of the people into a form of 'sovereignty' of fundamental rights and their interpreters." 240 In this way, the constituted sovereignty of the people would be transferred to the judges who are tasked with the interpretation and protection of fundamental rights. ${ }^{241}$ Consequently, an ex post facto solution in the form of a judicial review of popularly-enacted constitutional amendments is still not legitimate because it will usurp the sovereignty of the constituted people, even if one purports to defend the rights that are considered necessary for the free exercise of sovereignty.

\footnotetext{
${ }^{231}$ This term is borrowed from Melissa Schwartzberg's "democratic autophagy". See Schwartzberg, supra note 215 , at 157.

${ }^{232}$ Po Jen Yap, The Conundrum of Unconstitutional Constitutional Amendments, 4 GLOB. ConstituTIONALISM 114, 123-24 (2015).

${ }^{233} \mathrm{Id}$.

${ }^{234}$ Stacey, supra note 227 , at 614 .

${ }^{235}$ Yap, supra note 232, at 122 .

${ }^{236} \mathrm{Id}$.

${ }^{237}$ R. George Wright, Could a Constitutional Amendment Be Unconstitutional?, 22 LoY. UNI. L.J. 741, $753-54$ (1990).

${ }^{238}$ Yap, supra note 232, at 123.

${ }^{239} \mathrm{Id}$. at 129.

${ }^{240}$ Taillon, supra note 155 , at 552.

${ }^{241} I d$. at $552-53$.
} 
Instead, in answering the problem of knowing who may legitimately determine rights that are considered to be fundamental, Taillon advocated for an answer that is in line with the principle of sovereignty. In his view, "the only legitimate method ... to distinguish that which is fundamental from that which is not remains the one which is based on the judgment of the sovereign people."242 Thus, Taillon believed that once the mechanism of a constitutional referendum is embraced, one has to trust the judgment of the people. ${ }^{243}$ Such a solution would be aligned with the observation of Joel Colón-Ríos that "the fundamental or non-fundamental character of constitutional provisions is not static, but may be in a permanent state of flux: what is considered fundamental in a particular historical context might not be so considered at another time." 244

If we apply Taillon's solution to the context of constitutional amendments that are contrary to human rights, the constituted people are viewed as the most appropriate judge in determining the validity of the amendment. In this way, the "permanent state of flux" mentioned by Colón-Ríos is not entirely random but rather depends on the judgment of the constituted people. Consequently, if one wants to accept Taillon's solution, one must put faith in the constituted people that they would not only reject amendments that could lead to liberticide results but also safeguard the right of minorities. Such a faith could be misplaced on the occasion when the referendum is concerned with unpopular minorities such as immigrants ${ }^{245}$ or when the referendum itself is regarded as an occasion to cast a vote of no confidence or a protest vote against the ruling party. ${ }^{246}$ Nevertheless, from the pure perspective of popular sovereignty, the constituted people's judgment is still unassailable, and thus an ex post facto solution is still not palatable unless one accepts the transfer of the sovereignty of the people into the sovereignty of judges.

\section{E. Conclusion}

This research demonstrated that from the perspective of constituent-constituted duality, the only possible limitation to popularly-enacted constitutional amendments is an ex ante limitation. In contrast, an ex post facto limitation is illegitimate because it will usurp the sovereignty of the constituted people. Thus, in answering the question posed by the title of this article, the people can only be partially limited by human rights, and that is because of the constrained nature of the constituted people instead of the normative and universal characteristic of human rights themselves.

This finding implies that a human rights brake clause can and should be provided in constitutions to filter out a proposed amendment or popular initiative that could lead to the violation of human rights. Such a possibility was demonstrated by how Switzerland established mandatory provisions of international law as a limitation to popular initiatives. The legitimacy of such a clause should be further enhanced by a deliberative, inclusive, and participatory process despite the impossibility for the constituted people to transform into the constituent people. It is true that the enshrinement of a human rights brake clause is not a panacea to prevent all forms of human rights violation. The effectiveness of such a clause might also depend on the robustness of the ex ante control in practice. Nevertheless, it can at least minimize the occurrence of the awkward and difficult-to-reconcile scenario when human rights directly clash with popular sovereignty.

\footnotetext{
${ }^{242} \mathrm{Id}$. at $550-51$.

${ }^{243} I d$. at 589-90. See also Doyle, supra note 217, at 77 (suggesting that the people can still be bound by natural law and at the same time are the ones who may decide what natural law is).

${ }^{244}$ Colón-Ríos, supra note 145 , at 231.

${ }^{245}$ Stefanini, supra note 6 , at $376-80$.

${ }^{246}$ See Patrick Taillon, The Democratic Potentials of Referendum: Intrinsic and Extrinsic Limitation, in THE ROUTLEDGE Handbook to Referendums and Direct Democracy 180 (Laurence Morel \& Matt Qvortrup eds., 2017).
}

Cite this article: Nugraha IY (2022). Popular Sovereignty and Constitutional Referendum: Can “The People" be Limited by Human Rights?. German Law Journal 23, 19-43. https://doi.org/10.1017/glj.2022.2 